\title{
Construction of Financial Statement for Islamic Household
}

\author{
Ahmad ROZIQ1*, Zainuri ${ }^{2}$ \\ 1,2 Faculty of Economics and Business, University of Jember, East Jawa, Indonesia, \\ Email: ahmadroziq.feb@unej.ac.id \\ * Corresponding Author
}

\begin{abstract}
Received: 03.11.2021
Accepted: 19.12.2021

Published: 02.02.2022

DOI: 10.47750/QAS/23.186.32

Abstract

This study aims to investigate how to develop sharia accounting to compile Islamic household financial statements. The study was used qualitative research for analytical, empirical data. The respondents for the research are 5 Islamic housewives and accountant educators (accounting lecturers) who were selected by purposive sampling in East Java. The obtained data were analyzed via Miles Huberman's approach with three analytical elements. The results showed that Islamic household financial statements consisted of; (a) statement of financial position, (b) cash flow statement and, (c) statement of changes in funds. The Islamic accounting development model for Islamic household entities uses an integration, interaction, and evolution approach that was developed from empirical facts about the existence of financial statements occurring in Islamic households synchronized with the opinions of educators accountants about Islamic financial statements and then integrated with Islamic teachings.
\end{abstract}

Keywords: Development model, Financial statements, Household, Islamic accounting

\section{Introduction}

A family is the smallest community in a society because it consists of husband and wife (the smallest) or husband, wife, and children. Every family member should have a complementary role (Chudhuri, 2011). Husband and wife should have the rights and obligations of each and complement each other, including (1) each husband is obliged to provide religious and world education to his wife and children needed, (2) treat each other well, (3) maintaining each other's feelings, (4) do not reveal each other's secrets or disgraces, (5) husband and wife are equally loyal, (6) maintain each other's good name, (6) for husbands, provide a lawful living for wives and children, and (7) for wives, to take good care of her husband's wealth and trust.

The household life of each partner cannot be the same. Each family's journey certainly has its surplus and deficiency. When the initial principle of trust is built will begin to disappear, there will be mutual suspicion between husband and wife. This is what ultimately can lead to divorce. Data from Republika.co.id states that divorce rates in Indonesia have increased from year to year. This can be seen from the data ROL received from the Ministry of Religion (Kemenag) data submitted by the Chief of SubDirectorate of Anwar Saadi, Friday (11/14).

According to Raz-yurovich (2011), Sandstrom (2011), and Sakata (2011), research showed one of the causes of divorce is dishonesty or lack of good coordination between husband and wife in financial matters (income and outcome). This case shows that an accounting system is needed to bridge and eliminate the distrust of each husband and wife to their partner's wealth, whether financial or other things obtained by a married couple. This family accounting system makes it easier for husband and wife to see the household's financial strengths and financial weaknesses. Based on the letter Al Baqarah 282, Allah instructs us as individuals (families) to make financial reports, but in reality financial reports are not made by individuals for the benefit of the household, but the financial statements are only used and applied for the benefit of both private organizations (companies and non-profit organizations) and government organization.

According to Setiowati (2016), family is an important part in order to shape the character of a nation. If the family as a foundation of society is weak, then the community will be weak. Therefore, sociologists believe that various social problems such as moral crises, sexual violence, rampant violence, and all kinds of depravity in society result from weak institutional oversight in the family environment.

Islamic households differ from non-Islamic households, or it can be said that economic systems are also different. Islamic households have a basis to run their lives with faith in Allah SWT, which means, they consider fulfilling their needs and what they have is a deposit entrusted by Allah SWT to them. Wealth in Islamic households is believed as entrusted by Allah SWT. Islamic households must manage their finances so as not to violate Islamic law. As Allah SWT said, "Believe in Allah and His Messenger and spend out of that in which He has made you successors. For those who have believed among you and spent, there will be a great reward." (Al-Hadiid: 7). The Islamic household economy prioritizes primary needs over secondary and even tertiary needs. Suppose a household does not prioritize primary needs or even prioritizes secondary and tertiary needs. In that case, this will indicate that the household is doing things that do not follow Islamic law, spring, or wasteful.

Accounting itself in the household is very important because it can avoid financial problems (Manurung \& Sinton, 2013). Financial planning is essential for the needs of household life. Financial management in the household will look better if the wife controls it. This is because a wife looks more capable of controlling a process of every need in the household and can 


\section{GENERAL MANAGEMENT}

make budget plans that are needed simply to achieve a separate satisfaction and prevent disputes within the household.

Indonesian Muslims are citizens who should pay taxes. In addition, Islamic households must also carry out the commands of Allah SWT, namely the obligation to pay zakat, which is the third pillar of Islam. The following is the proposition that shows the obligation to do zakat: transliteration: " Take Sadaqah (alms) from their wealth to purify them and sanctify them with it, and invoke Allah for them. Verily! Your invocations are a source of security for them, and Allah is All-Hearer, All-Knower.". (AtTaubah:103).

The verse shows that Muslims who have assets must set aside a portion to pay zakat following Islamic law. Islamic households not only estimate the assets they have but must record to know their net income and assets as a whole which must be paid in part for zakat or tax so that the existence of Islamic household financial statements can facilitate an Islamic household in managing its finances to be more effective in terms of carrying out obligations following Islamic law. Based on these facts, it is very necessary to do research or study to examine how the model of development of Islamic accounting in Islamic household entities.

\section{Literature Review}

\section{Shariah Enterprise Theory}

According to Triyuwono (2006a, p. 350), sharia accounting is a form of management accountability towards company owners (stockholders) and as accountability to stakeholders and God. In principle, shariah enterprise theory provides a form of primary responsibility to God (vertical) which is then redefined in the form of responsibility to humans (horizontal) and the natural environment. The statement explains that Allah as God Almighty has the highest position so that his people must be responsible for everything that is done in the world. According to Slamet in Triyuwono (Triyuwono, 2006b, p. 352), the basis used to establish the concept of Enterprise Theory is God as the Creator and Sole Owner of all resources in the world. So, what applies in the Shariah Enterprise Theory is God as the primary source of trust because $\mathrm{He}$ is the absolute sole owner. Whereas in principle, the resources in this world are trustworthy from Allah, which is inherent in a responsibility to use in the manner and purpose set by the Provider of Trust.

\section{Development of Islamic Accounting}

Islamic accounting theory is developed by internalizing Islamic values into enterprise theory. One of the developments in sharia accounting is the use of sharia enterprise theory in justifying sharia accounting. Islamic accounting is not only to serve the interests of the stockholders but also all parties involved or stakeholders. Religious rules bind Sharia-based financial statements as the basis and spirit of the nature of shari'ah accounting. Islamic accounting has the advantage of "trustworthiness" and accountability in delivering information and accountability for its accuracy. Decisions and policies can be considered because they are following the actual real conditions compared to conventional accounting. According to Yahya (2012), there are three approaches in formulating sharia accounting forms. Namely as follows:

Method 1. The development of shari'ah accounting must still be sourced from Islam, namely the Qur'an and the Hadith, as briefly explained in Figure 1 below.

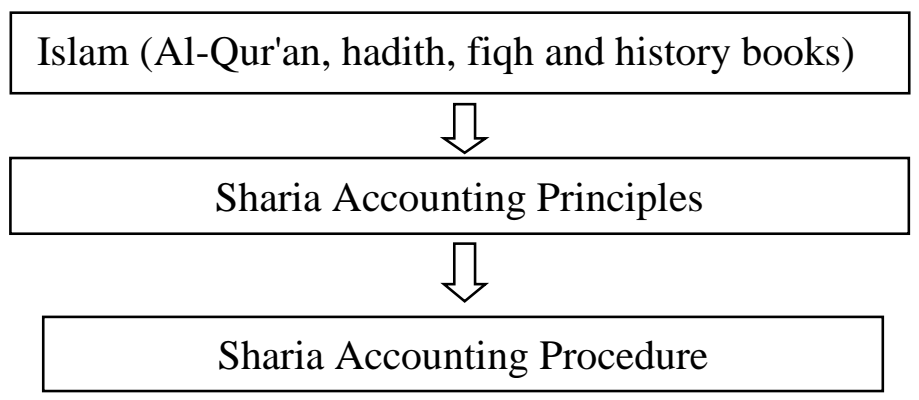

Figure 1: Idealist Approach in the Development of Islamic Accounting

Method 2. If current accounting is in line with sharia, it can be accepted. Conversely, if it contradicts the Shariah, then it is rejected

\begin{tabular}{|l|}
\hline Conventional Accounting Theory and Concepts \\
\hline Islam (Al-Qur'an, hadith, fiqh and history books) \\
Sharia Accounting Principles and Procedures \\
\hline
\end{tabular}

Figure 2: Pragmatic Approach in the Development of Islamic Accounting

Method 3 of Islamic accounting results from human understanding capturing the signal of the truth of science that comes from absolute truth (nash) and empirical truth. 


\section{GENERAL MANAGEMENT}

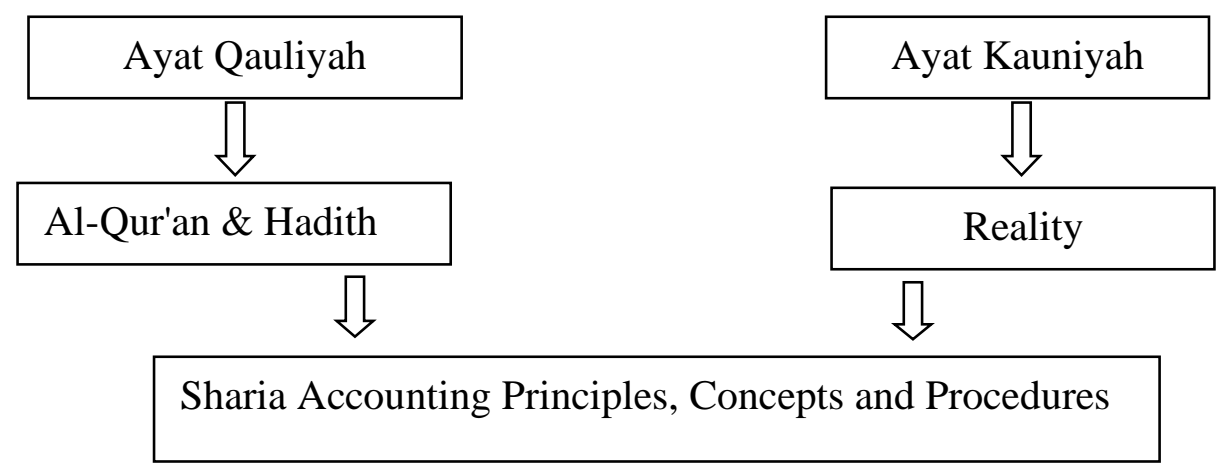

Figure 3: Hybrid Approach in the Development of Islamic Accounting

\section{Household Accounting}

The role of accounting in the household is very important because it can avoid financial problems. The inability to control money impacts adversity, anxiety, and illness. Financial planning is very important for the needs in the household life. Financial management in the household will look better if it is controlled by the wife. This is because a wife will look more able to control a process of every need in the household and make budget plans that are needed simply to achieve a separate satisfaction and prevent disputes in the household. Financial planning needs to be done by individuals and families. This is because financial planning becomes important for a better life. Without excellent financial planning, most people feel difficulties in their finances and an inevitable increase in suffering.

Household accounting is easy to learn but negligent to apply. The difficulty of applying is not due to the difficulty of the method and principles of recording, but the difficulty arises from the reluctance of a family to implement it. Usually, the family ignores the recording of income and expenses that occur in the household. They consider this and trivial, so they are reluctant to do it. However, many benefits can be obtained by implementing household accounting. One example is by keeping records on family financial transactions. A family can see how much benefit the family gets from the transaction. In addition, families can find out which expenditure items are considered unnecessary so that in the future they can save more.

\section{Methodology}

The type of research used is exploratory - constructive research and action research conducted in several households in East Java. Participants were 5 Islamic homemakers and accountant educators were selected by purposive sampling in East Java (Moleong, 2005). Purposive sampling is the technique of sample used the qualities of participants or choose participants based on knowledge and experience (Etikan, Musa, \& Alkassim, 2016).

Primary and secondary data were analyzed using the constructive-exploratory method and the data triangulation method. The types of data used in this study are primary and secondary data. Primary data is from respondents' perceptions/opinions of household heads and household finances and accounting for users, accountability, transparency, and usefulness of household financial reports. In contrast, secondary data is in document data, records, or household financial reporting. The data collected were analyzed descriptively-qualitatively. Data processed using the Miles and
Huberman approach includes; (1) data collection, (2) data reduction, (3) data display, (d) conclusion drawing/verification (Kasiram, 2010; Miles, Huberman, \& Saldana, 2014; Nawawi, 2012).

The methods or data collection methods used in this study are as follows:

\section{Documentation}

This method is used to explore secondary data in financial data, household activities and household financial reports, financial records.

\section{Interview}

An interview is a method of collecting data through questions that are asked verbally and directly that is done face to face. Interviews can be conducted with heads of households and financial and household accounting experts.

\section{Focus Group Discussion (FGD)}

Focus Group Discussion (FGD) is a method in which data collection and problem-solving are raised in research that is sought for solutions to problem-solving in groups referring to existing facts by involving stakeholders and experts/experts.

\section{Observation}

Direct observations are needed to complete the data analysis, especially those relating to accountability and transparency of sources and uses of funds and household financial reports.

\section{Results And Discussion}

Based on the results of interviews with experts, accounting lecturers spread in East Java and the results of a survey of five Islamic households that have made a financial statement, it was concluded that the proper Islamic household financial statements consisted of; (a) fund change report, (b) statement of financial position, (c) statement of cash flows. The Fund Amendment Report is a report that provides information on fund income and fund disbursements that affect net assets owned by households (Suffitra, 2015). The Financial Position Report informs the position of assets, liabilities, and net assets at the end of the period. The value of each account in the statement of financial position is taken from the trial balance after adjustment, except for the net asset account obtained from the change in funds report. Cash flow statement is a summary of cash in and cashes out in the household. The cash flow statement is used to evaluate household cash receipts and disbursements that have 


\section{GENERAL MANAGEMENT}

already taken place or daily costs and to plan future investment and financing activities.

The income and expenditure report is a report that provides information about the income and expenditure that will affect the net assets owned by the household. The accounts included in the statement of income and expenditure of funds: (a) income consists of basic income and supporting income, (b) Expenditures consist of routine and non-routine expenses, and (c) net fixed assets

The cash flow statement summarizes cash in and cashes out in the household (Noorhaslinda, Nasir, Nik, \& Kamil, 2011). The cash flow statement is used to evaluate household cash receipts and disbursements that have already taken place or daily costs and to plan future investment and financing activities. Activities in the cash flow statement include: (a) main household activities showing all income received and expenditure for household needs, (b) household investment activities are investments made for future investment. Household investment, namely zakat, which is investment cannot be withdrawn but is capital in the hereafter for the implementation of obligations stipulated in Islam, namely paying zakat and (c) funding activities are activities related to Islamic fund lending in the household to fund a household's needs such as houses, vehicles, and so on.

\section{Construction of Financial Statements for Islamic Household}

Based on the results of interviews with experts, they are accounting lecturers spread across East Java. The results of a survey of five Islamic households produced a report on changes in funds, cash flow statements, and statements of financial position. Ibu Siti Hana's household financial data in the form of reports on money receipts and disbursements and household asset data are constructed to report changes in funds (as in table 1). Fund Amendment Report is a report that provides information on fund income and fund disbursements that will affect the net assets owned by households.

\begin{tabular}{|l|l|}
\hline Changes in net reserve funds & Amount (USD) \\
\hline Income: & \\
\hline 1. Basic income & $\$ 274.19$ \\
\hline 2. supporting income & $\$$ \\
\hline Total Income & $\$ 274.19$ \\
\hline Routine expenses & $(\$ 36.84)$ \\
\hline 1. Expense needs per month & $(\$ 92.17)$ \\
\hline 2. Household consumption & $(\$ 24.60)$ \\
\hline 3. Electricity and telephone charges & $(\$ 8.08)$ \\
\hline 4. Transportation expense & $(\$ 77.33)$ \\
\hline 5. Rent for residence & $(\$ 239.02)$ \\
\hline Total routine expenses & $\$ 35.17$ \\
\hline Total household reserve funds & \\
\hline Non-routine expenses & $(\$ 7.03)$ \\
\hline 1. wedding expenses & $(\$ 11.03)$ \\
\hline 2. Recreational / entertainment expenses & $(\$ 7.03)$ \\
\hline 3. Zakat & $(\$ 25.09)$ \\
\hline Total non-routine expenses & $\$ 10.08$ \\
\hline increase / decrease in net reserve funds & \\
\hline Change in Fixed Assets Net & \\
\hline Accumulated depreciation & $(\$ 229.08)$ \\
\hline Increase/decrease in fixed assets net & $(\$ 219)$ \\
\hline Decrease in net assets &
\end{tabular}

Table 1: Siti Hana Household Funds Change Report for August 2019

The second financial statement construction, Mrs. Siti Hana's household financial data in the form of reports on money receipts and money disbursements and household asset data, is constructed to be a statement of cash flows (as in table 2). The cash flow statement is a summary of cash in and cashes out in the household. The cash flow statement is used to evaluate household cash receipts and disbursements that have already taken place or daily costs and to plan future investment and financing activities.

\begin{tabular}{|l|l|}
\hline Basic Household Activities & Amounts \\
\hline Cash inflows from main activities & \\
\hline 1. Cash from principal income & $\$ 274.19$ \\
\hline 2. Cash from supporting income & $\$-$ \\
\hline & $\$ 274.19$ \\
\hline Cash outflows from principal activities & \\
\hline 1. Expense needs per month & $(\$ 36.84)$ \\
\hline 2. Daily expense & $(\$ 92.17)$ \\
\hline
\end{tabular}




\section{GENERAL MANAGEMENT}

\begin{tabular}{|l|c|}
\hline 3. Electricity and telephone charges & $(\$ 24.60)$ \\
\hline 4. transportation expense & $(\$ 7.08)$ \\
\hline 5. Rent a residence & $(\$ 77.33)$ \\
\hline 6. Wedding expenses & $(\$ 7.03)$ \\
\hline 7. Recreational / entertainment expenses & $(\$ 11.03)$ \\
\hline Total outflow & $(\$ 257.13)$ \\
\hline Household Investment Activities & \\
\hline 1. Net cash used for alms & $(\$ 7.03)$ \\
\hline Total cash flow & $\$ 10.03$ \\
\hline Cash and cash equivalent at early month & $\$ 351.53$ \\
\hline Cash and cash equivalents at the end of the month & $\$ 361.58$ \\
\hline
\end{tabular}

Table 2: Siti Hana Household

Cash Flow Statement Report for August 2019

The construction of the third financial statement, Mrs. Siti Hana's household financial data in the form of reports on money receipts and expenditure of money and household asset data, is constructed to become a statement of financial position (as in table 3). The Financial Position Report informs the position of
Islamic household assets, liabilities, and net assets at the end of the period. The value of each account in the statement of financial position is taken from the trial balance after adjustment, except for capital accounts obtained from the statement of changes in net assets.

\begin{tabular}{|l|l|l|}
\hline \multicolumn{1}{|l|}{ Amount } \\
\hline ASSET & Debet (USD) & Credit (USD) \\
\hline CURRENT ASSETS & & \\
\hline Household cash & $\$ 361.58$ & \\
\hline Total Current Assets & & $\$ 361.68$ \\
\hline FIXED ASSETS & $\$ 40,799.67$ & \\
\hline House of residence & $\$ 4,079.97$ & \\
\hline Car & $\$ 442.00$ & \\
\hline Motor cycle & $\$ 605.20$ & \\
\hline Equipment & & $\$ 223.40$ \\
\hline Accumulated depreciation & & $\$ 45,703.43$ \\
\hline Total fixed assets & & $\$ 46,053.15$ \\
\hline Total Asset & $\$-$ & \\
\hline liabilities & $\$-$ & \\
\hline NET ASSETS & & $\$ 361.68$ \\
\hline Net Reserve Funds & & $\$ 45,703.43$ \\
\hline Fixed Assets Net & & $\$ 46,053.15$ \\
\hline Total Liabilities and Net Assets & & \\
\hline
\end{tabular}

Table 3: Siti Hana Household

Household Financial Position Report for August 2019

\section{Islamic Accounting Development Model}

Based on these results, the Islamic accounting development model on Islamic household entities is illustrated in the scheme below:

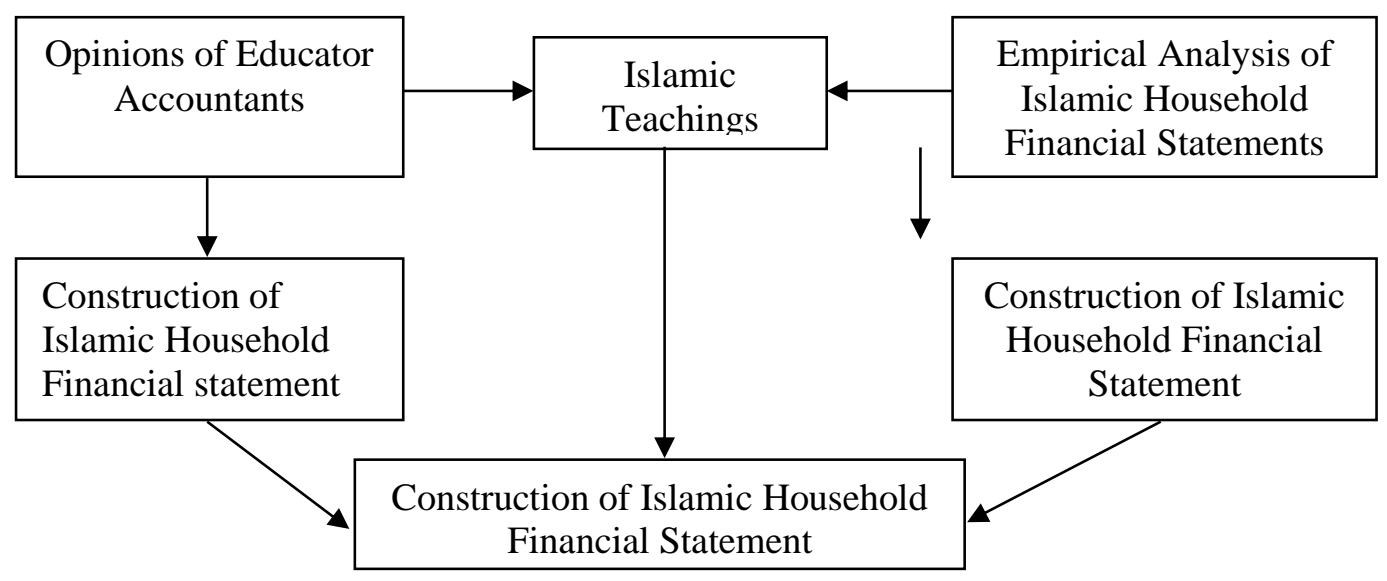

Figure 4: Islamic Accounting Development Model 


\section{GENERAL MANAGEMENT}

The development model of sharia accounting for Islamic household entities uses an integration, interaction, and evolution approach developed from empirical facts of financial statements that occur in Islamic households with Islamic teachings and combined with the opinions of educators accountants who are integrated with Islamic teachings. After that, empirical facts are sought similarities and differences with the opinions of educators accountants and carried out continuously.

Based on this study, an important factor is understanding the important role of Islamic household financial statements. Islamic household financial statements are used to make decisions about what expenses are considered not so essential and considered too wasteful through an evaluation of the Islamic financial statements made(Suarni \& Sawal, 2020). The financial statements also show how much reserve funds are saved from being allocated unexpected needs and future needs. In modern times it seems that money has become the most important thing in people's lives (Manurung \& Sinton, 2013; Yulianti, 2016) with an understanding of accounting in order to control the amount of expenditure so that it does not exceed the amount of income. The basic understanding of the concept of Islamic accounting still seems to be the main obstacle in Indonesia, especially since Islam is the majority religion owned by the community.

In addition, the concept of Islamic accounting for households is able to improve communication between nuclear families so that problems that arise due to economic insufficiency will be reduced. Based on 2020 data, economic factors are the second factor that causes the divorce rate in Indonesia to increase. The bookkeeping of income and expenses can help alleviate this problem through lifestyle control. The concept of Islamic accounting not only helps regulate worldly life but also invests in the afterlife through zakat and alms, as well as increasing the responsibility of a wife to her husband regarding financial management (Mulyani \& Budiman, 2018).

\section{Conclusions}

Based on this study, it can be concluded Islamic household financial statements are not only able to manage household finances more optimally, but Islamic household financial statements are a form of accountability to the husband and accountability to God that a wife can be better at managing finances which are entrusted by Allah SWT. If a household cannot manage its household finances properly, it will trigger household conflict and lead to a divorce from the economic problems in the household.

The high divorce rate caused by economic factors makes financial statements a solution so that communication between families can run properly with their respective roles. In addition, financial statements here are fundamental from an economic point of view, which can practice Islamic values in the form of investments in the afterlife. The lack of use of accounting in the household is the biggest challenge in finding respondents. The lack of knowledge and understanding of Islamic accounts in accounting is the basic reason why many household sectors have not implemented the use of accounting.

Islamic household financial statements consist of; (a) statement of financial position, (b) statement of cash flows, and (c) statement of changes in funds. The development model of sharia accounting for Islamic household entities uses an integration, interaction, and evolution approach developed from empirical facts of financial statements that occur in Islamic households with Islamic teachings and combined with the opinions of educators accountants who are integrated with Islamic teachings. After that, empirical facts are sought similarities and differences with the opinions of educators accountants and carried out continuously.

\section{References}

[1] Chudhuri, S. (2011). Social Development and The Family. In Social and Cultural Development of Human Resources.

[2] Etikan, I. (2016). Comparison of Convenience Sampling and Purposive Sampling. American Journal of Theoretical and Applied Statistics, 5(1), 1. doi:10.11648/j.ajtas.20160501.11

[3] Kasiram. (2010). Qualitative and Quantitative Research Methodologies. Jakarta: UIN Maliki Press.

[4] Manurung, D. T. ., \& Sinton, J. (2013). The Urgency of the Role of Accounting in the Household(Phenomenological Studies for Accounting Lecturers at the University of Widyatama Bandung). Scientific Journal of Accounting and Humanities, 3(1), 892-911.

[5] Miles, M. B., Huberman, A. ., \& Saldana, J. (2014). Qualitative Data Analysis. (H. Salmon, K. Perry, \& K. Koscielak, Eds.) (3rd ed.). California: SAGE Publication, Inc.

[6] Moleong, L. J. (2005). Qualitative Research Methodology (Edition of). Bandung: PT. Remaja Rosdakarya.

[7] Mulyani, S., \& Budiman, N. A. (2018). The Importance of Household Accounting in Improving Islamic Life. Equilibrium:Sharia Economic Journal, 6(2), 206. https://doi.org/10.21043/equilibrium.v6i2.3707

[8] Nawawi, I. (2012). Qualitative Research Methodology. Jakarta: CV. Dwiputra Pustaka Jaya.

[9] Noorhaslinda, K. A. R., Nasir, A., Nik, H. N. M., \& Kamil, N. F. (2011). Analysis of Income and Expenditure of Households in The East Coast of Peninsular Malaysia. Journal of Global Business and Economics, 2(1).

[10] Raz-yurovich, L. (2011). Economic Determinants of Divorce Among Dual-Earner Couple: Jews in Israel, 49.

[11] Sakata, K., \& Mckenzie, C. . (2011). Social Security and Divorce in Japan. Mathematics and Computer in Simulations, 81(7), 1507-1517.

[12] Sandstrom, G. (2011). Socio-economic Determinants of Divorce in Early Twentieth-century Sweden. History of Family, 16(3), 292-307.

[13] Setiowati, N. E. (2016). Women, livelihood strategies, and household accounting. Al-Amwal: Journal of Economic and Sharia Banking, 8(1).

[14] Suarni, A., \& Sawal, A. R. (2020). The Role of Accounting in the Household and the Application of Islamic Household Financial Management during the Covid-19 Pandemic. ASSETS, 10(2), $110-129$

[15] Suffitra, R. (2015). Application of Zakat Accounting at Zakat Management Institutions Based on PSAK 109 Regarding Accounting for Zakat and Infaq / Alms (Case Study on the Regional Amil Zakat Agency of Banyuwangi Regency). Student Scientific Articles, 1-6.

[16] Triyuwono, I. (2006a). Islamic Accounting Perspective, Methodology and Theory. PT. Raja Grafindo Persada.

[17] Triyuwono, I. (2006b). Islamic Accounting Perspective, Methodology and Theory. PT. Raja Grafindo Persada.

[18] Yulianti, M. (2016). Accounting in the Household: A Phenomological Study on Accountants and Non-Accountants. Journal of Accounting and Management, 11(2), 62-75. 